\title{
The Chechen-Russian Conflict: The Spiral of Hostilities
}

\author{
Tanya Basok
}

The present military intervention in Chechnya has been explained by some analysts by the economic competition over the control of oil, while other analysts have drawn attention to the religious nature of the conflict. While bearing a kernel of truth, both approaches are reductionist. In this article I will attempt to explain the present eruption of hostilities as the result of both past and present failures to address the conflict that has its roots in the military conquest of the Caucasus.

In ethnic conflict studies there is an on-going debate between those who argue that in any poly-ethnic society conflict between groups or repression of one or several ethnic groups is inevitable and those who suggest that it is possible to find a formula that would allow various ethnic groups to coexist peacefully, sharing access to power and economic resources, in spite of their cultural differences. The former, known as the 'plural society theorists' (Furnival 1967,Smith 1971), affirm that stable democratic societies are impossible in poly-ethnic states and that unity in such societies can be sustained only by force. Others, like Ryan (1990), for instance, criticize this approach for several reasons: it ignores the possible existence of crosscutting cleavages between ethnic group; itignores the fluid and changing nature of ethnic identification; and it leaves out the possibility of the creation of formal rules of $\mathrm{mu}$ tual accommodation (Ryan 1990, 1213). Instead, a number of authors have attempted to suggest a model for conflict regulation between ethnic groups living in the same society (Ryan 1990, McGarry and O'Leary 1993).

With respect to the ChechenRussian conflict, it would be easy to

Professor Basok teaches at the Department of Sociology and Anthropology, University of Windsor, Canada. argue that the Chechen 'national character' and aspirations are incompatible with the Russian ones. Indeed, this argument is exploited by leaders on both sides of the conflict. Yet, the present conflict is a direct result of the failure to find accommodation acceptable for both parties, and unless the current government reverses the policy trend it inherited from both the preRevolutionary and the Soviet government, Chechnya will always remain an explosive area. More specifically, I suggest in this article that the present conflict is a cumulative result of hostile policies pursued by the Russian government vis-a-vis the Chechens for over a century. Among these are the following: first, ruthless suppression of every uprising with no attempt to negotiate a settlement; second, decades of political repression; third, forced relocation and poor record of reintegration; fourth, forced assimilation; fifth, failure to recognize demands formulated by Chechen separatists and negotiate a settlement with them; and sixth, escalation of hostilities due to war-related cruelty

\section{The Conquest and Resistance}

Since the 16th century Russian Czars undertook several attempts to incorporate the North Caucasus into Russia, at times through peaceful means (such as intermarriage) but mostly by means of military campaigns. North Caucasian peoples resisted these attempts fiercely (Avtorkhanov 1992; 149-50). In 1859, after twenty-five years of guerilla warfare, led by Imam Shamil in the Chechen mountains, the Russian rule was nevertheless established (Akiner 1983, 176). Yet, the Caucasians made every attempt to overthrow this foreign rule. In 1864, fearing new revolts in the Caucasus, the Russian government exiled masses of Chechens (as well as other Caucasian peoples) to Turkey. But this measure did not prove sufficient and in 1877 a popular uprising flared up in Chechnya and Daghestan. The revolt was ruthlessly suppressed (Avtorkhanov 1992, 15051). Thus started the upward spiral of uprisings, followed by retaliation by the Russian and then the Soviet governments.

\section{Uprisings and Suppression}

The Soviets assumed control in the Chechen territory at the end of 1917. Then the territory was occupied by the White Army and in 1920 the Soviets reoccupied it once again. In August 1920 , an anti-Soviet uprising flared up in the mountains of Chechnya, Ingushetia and Daghestan, and lasted for one year. This uprising was crushed and the Chechen Soviet autonomous region was created on November 20, 1922 (Avtorkhanov 1992, 153-56). General disarmament followed.

Yet, it did not prevent another uprising in the Fall of 1929, when the insurgents occupied all the rural and regional institutions, burned official archives, and arrested the staff of the regional government, demanding autonomy (Avtorkhanov 1992, 15658). In the middle of December 1929, regular detachments of the Red Army began to arrive and after several months of fierce fighting with heavy losses, the uprising was once again suppressed. Yet peasant revolts continued with regularity throughout the 1930s.(Avtorkhanov 1992, 165). Some 'mullahs' and 'nationalists,' who had been excluded from the village by the Soviets in 1937, went into the mountains and in early 1940, Khasan Israilov proclaimed the 'war of liberation' and appointed a 'temporary revolutionary people's government of Chechnya and Ingushetia.' They fought for a 'free Caucasus' and they managed to control several regions in the mountains until 1942 (Simon 1991, 202-3). 


\section{Political Repression}

Political repression was also used by Soviet authorities against Chechen leaders as a preventative measure to intimidate and control them (Avtorkhanov 1992, 165-71). It culminated on July 28,1937 , when Stalin's Security Police representative in the Caucasus gave instructions to the assembled Party leaders to start a 'super-purge.' As a result, 14,000 people (or one in thirty) in the Chechen-Ingush republic were either arrested and executed or deported (Simon 1991, 202-3). Arrests continued until November 1938 (Avtorkhanov 1992, 176).

\section{Deportation}

Even though the majority of Chechens opposed the Germans (Akiner 1983, 176), collaboration with the Nazi occu- defeat (Avtorkhanov 192, 180). Furthermore, the Soviet government accused the Chechens (as well as other Caucasian peoples) of collaboration with the Germans, even though the Chechen territory was never under Wehrmacht occupation (Simon 1991, 202). In February 1944, the Red Army arrested masses of Chechens, many of whom were executed without trial (Avtorkhanov 1992, 185). The alleged collaboration was used by the Soviet government to deport some 408,000 Chechens to compulsory settlements in Central Asia and Siberia in March 1944 (Simon 1991, 201). Chechens were the most numerous of the deported Caucasian peoples. Simon (1991, 202) observes that deportation was a policy aimed at breaking this region's long-lasting anti-Soviet and national resistance, which had triggered several armed rebellions. After the depor-

\section{The present conflict is a direct result of the failure to find accommodation acceptable for both parties, and unless the current government reverses the policy trend it inherited from both the pre-Revolutionary and the Soviet government, Chechnya will always remain an explosive area.}

piers was used as an excuse to deport over four hundred thousand Chechens to Kazakhstan and Central Asia. During the Second World War Chechen soldiers experienced tremendous difficulties in the Russian Army both because they often did not understand Russian and because their dietary prohibitions were not respected. Mass desertions by the Chechens from the Red Army can be attributed to these difficulties. Eventually, neither Chechens nor the Ingush were accepted into the Red Army and those already serving were dismissed. However, two divisions of volunteers from the Chechen-Ingush Republic were formed, but these were not officially recognized nor supplied with tanks and artillery. Being poorly equipped, the divisions found it difficult to resist the Germans advancing towards Stalingrad. Even though the entire southern front collapsed, the ChechenIngush population was blamed for the tation of the Chechen and Ingush, the names of towns, villages and regions changed and Russians and members of other ethnic groups were allowed to settle there (Simon 1991, 203).

In the 1950s, Caucasian people started returning to their villages, and the Khrushchev government that was in power did not place any explicit obstruction. By the Summer of 1954, many Caucasian people perceived that the government was relaxing its control, and thousands of families, mostly Chechen and Ingush, began their move home. Even though some arrests and compulsory transport back to Central Asia followed, the number of Chechens and Ingush returning to the Caucasus continued increasing, reaching a total of 25,000 to 30,000 by 1956 . On November 24, 1956, the Central Committee issued a decree reinstituting the right of the deported peoples to return. In January 1957, the Chechen-Ingush Autonomous Soviet
Socialist Republic was re-established, and between 1957 and 1960 they were allowed to return (Simon 1991, 24143).

Although the authorities promised the returning people credit, housing and work, the re-integration of repatriated people proceeded at a very slow pace. The return of the Chechens and Ingush caused the gravest and most lasting tensions. Housing and employment were insufficient, partly because many more families returned to the homelands than the plan had anticipated. Tensions grew between the returning Chechens and the Russians who had settled in their villages and cities. From August 24 to 28, 1958, Groznyi witnessed great disturbances between the Chechen, Ingush and Russian populations. Troops were brought in to re-establish order and peace. The government did not try any Russian instigators for the disturbances but placed the blame entirely on Chechen and Ingush 'bourgeois nationalism' (Simon 1991, 243-44).

\section{Forced Assimilation Policies and Resistance}

The Soviet government adopted policies of forced assimilation of the Caucasian people, but in spite of their attempts, both the clan system and militant Sufi brotherhood survived well into the Soviet rule. Many clans kept land in their possession, although the Soviets labelled it as kolkhoz (Simon 1991, 202; Akiner 1983, 176). The deportation of Chechens to Central Asia reinforced both the Sufism and the clan system (Simon 1991, 348). Religion and kinship were employed to sustain solidarity of the deported people (Bennigsen Broxup 1992a, 7-8). After the repatriation, the Soviet authorities once again tried to suppress the Chechen culture: Chechens were not allowed to teach their languages at school, to have mass-media in their language or to engage in any ethnic cultural activities (Simon 1991, 243). All mosques were closed until 1978 (Bennigsen Broxup 1992a, 7). Still, their religion proved to be resilient and today about 150,000 to 200,000 people are 
members in the Sufi brotherhood in Chechno-Ingushetia. The Sufibrotherhood enjoys as much prestige as it did before the Revolution (Bennigsen Broxup 1992a, 7-8).

\section{Stereotyping}

As far back as 1834, a Russian civil servant described the Chechens as a nation 'remarkable for her love of plunder, robbery and murder, for her spirit of deceit, her courage, reckless- of the Chechen Congress included free elections, and a new constitution and citizenship law. It insisted on the need for a peace treaty between Russia and Chechnya preceded by an unconditional recognition of the right of the Chechen people to sovereignty, trial of those guilty of genocide against the Chechen nation, payment of compensation for crimes against the nation and the return of national patrimony. After the failure of the coup, on August 22,

These atrocities only reinforce attitudes of hostility, suspicion and even hatred, that had existed on both sides before the armed conflict started. The escalation of violence makes it even more difficult for the two sides to find common grounds. In the atmosphere of heightened negative emotions, it would be nearly impossible to adopt measures needed for the process of peace building to begin.

ness, resolution, cruelty, fearlessness, her uncontrollable insolence and unlimited arrogance.' And he proposed that "they only way to deal with this ill-intentioned people is to destroy it to the last' (cited in Bennigsen Broxup 1992a, 10). Similarly today, Chechens are frequently portrayed as 'criminals,' 'Mafia,' 'drug traffickers' and 'armed bandits' (York 1995a) and certain measures have been taken by Russian authorities to harass and deport Chechens living in Moscow (Gáry 1993, Caplin 1993, York 1995b).

\section{Failure to Recognize Chechen's Political Aspirations}

The National Chechen Congress held an inaugural meeting on 23-25 November 1990, in Groznyi. On November 27, under pressure from the Congress, the Chechen-Ingush Supreme Soviet proclaimed the Republic's sovereignty. At that time, the ambitions of the movement were moderate; namely to raise the state of their region from autonomous to federal republic which would enable them to sign a union treaty with the USSR. By June 1991, their position became more radical. General Dzhokhar Dudaev, the chairman of the National Congress, expressed full support for the disintegration of the Soviet Union. Demands
1991, the Chechen opposition demanded the resignation of the local government and new elections (Bennigsen Broxup 1992b, 85-87). None of these demands were accepted by Russia. Since August 1991, Moscow tried persistently to vilify the Chechen opposition and to distract attention from the main issue expressed by Dudaev. Moscow responded by organizing counter-rallies, letters to Moscow newspapers complaining about the 'undemocratic' and 'unconstitutional' behaviour of the national Chechen Congress, encouraging the warlike ambitions of the Cossack colonies, painting the opposition as bandits' and 'criminals' and by military threats.

Nevertheless, on October 27, 1991, Dudaev was elected president of Chechnya by an overwhelming majority (Bennigsen Broxup 1992b, 231-35). Since then, Moscow's attempt to discredit Dudaev and his supporters grew only stronger. Unsuccessful in their efforts to depose Dudaev from his post and to quench separatist aspirations, the Russian Army invaded Chechnya on December 11, 1995.

\section{Escalation of Violence}

Once the war started, atrocities were committed by both sides. Russian sol- diers have been accused of routine violations of basic rights, including beating, torturing and killing civilians, looting and vandalizing their property, and setting the reign of terror in parts of Chechnya brought under their control. On the other hand, Russian soldiers justify the mistreatment of Chechens as retaliation for the atrocious way in which Russian prisoners were treated by the Chechens in the first days of this year. Dozens of captured Russian soldiers were tortured, mutilated and publicly executed. Local Russians were not allowed to bury the bodies abandoned in the streets (Gallagher 1995). These atrocities only reinforce attitudes of hostility, suspicion and even hatred, that had existed on both sides before the armed conflict started. The escalation of violence makes it even more difficult for the two sides to find common grounds. In the atmosphere of heightened negative emotions, it would be nearly impossible to adopt measures needed for the process of peace building to begin.

In sum, the eruption of violence that we witness today in Chechnya has its roots in the conquest of the Caucasus by Russia in the mid-nineteenth century. Since then, relations between Chechnya and Russia have been characterized by a never-ending spiral of hostilities which the Russian government had tried to regulate only by hegemonic means, such as suppression, political repression, and deportation. In addition, the Soviet authorities have tried to destroy Chechen culture, religion and traditions. In response, the Chechens have continued their resistance, both at the cultural and at the political level, never having submitted themselves to the Russian rule.

Once again,they tried to free themselves of Russian control and once again, Moscow cracked down by using excessive violence. Once it started, it led to escalation on both sides of the conflict. Until Moscow recognizes the legitimacy of some of the concerns raised by Chechen people and attempts to negotiate their demands, more blood will be shed on the Chechen land. 